\title{
Evaluation of Five Recommended Acaricides Against the Old World Date Mite, Oligonychus afrasiaticus (McGregor) (Acari: Tetranychi- dae) Infesting Date Palm Under Field Conditions in the New Valley, Egypt
}

\author{
Fakeer, M. M.; A.M. Salman and S.A. Eraky \\ ${ }^{1}$ Plant Protection Dep., Fac., of Agric., The New Valley Univ., Egypt \\ ${ }^{2}$ Plant Protection Dep., Fac., of Agric., Sohag Univ., Egypt \\ ${ }^{3}$ Plant Protection Dep., Fac., of Agric., Assiut Univ., Egypt
}

Received on: 29/1/2019

Accepted for publication on: 28/2/2019

\begin{abstract}
The date palm, Phoenix dactylifera L. (Arecaceae) is one of the most important fruit trees cultivated in the New Valley Governorate, Egypt. The old world date mite, Oligonychus afrasiaticus (McGregor, 1939) is considerd as a major pest of date palm orchards in the New Valley Governorate. Herein, the toxicity of five recommended acaricides [abamectin $(1.8 \% \mathrm{EC})$, chlorfenapyr $(36 \% \mathrm{SC})$, fenopyroximate $(5 \% \mathrm{EC})$, cyflumetofen $(20 \% \mathrm{SC})$ and hexythiazox $(10 \% \mathrm{WP})]$ were evaluated against the $O$. afrasiaticus in date palm, $P$. dactylifera (cultivar Siwi). Trials were conducted at the field of Plant Protection Department, Faculty of Agriculture, New Valley University. The recommended concentrations of each pesticide were evaluated on $O$. afrasiaticus adults. Results were recorded after 1, 3, 7, 14 and 21 days. Abamectin (1.8\% EC) and chlorfenapyr ( $36 \% \mathrm{SC})$ were considered the most potent pesticides among all the pesticides tested. The reduction percentages were 90.07 and 87.77 , followed by fenopyroximate (85.22), cyflumetofen (79.94) and hexythiazox (62.89). These acaricides have been used as the first choice and considered encouraging trends in controlling O. afrasiaticus in the New Valley Governorate, Egypt.
\end{abstract}

Keywords: Oligonychus afrasiaticus, Acaricides, Date palm, Toxicity, New Valley,

Egypt.

\section{Introduction}

The date palm, Phoenix dactylifera $\mathrm{L}$. (Arecaceae) is the strategic crop and main source of income for oasis farmers. It is the richest food sources of energy for the people living in southern parts of Iran, Middle East, north of Africa and elsewhere. More than one million palm trees are cultivated for local consumption and exportation in the New Valley Governorate. The Middle East is the source of two thirds of the world dates. The major date producers are: Egypt, Iraq, Iran, and Saudi Arabia. In the New Valley, the date palm trees are liable to be attacked by several pests and disease carriers such as: the spider mite, Eutetranychus palmatus Attiah (Tetranychidae), the red palm mite, Raoiella indica Hirst, and the red and black flat mite, Brevipalpus phoenicis (Geijskes), (Tenuipalpidae) (Negm et al., 2015).

The old world date mite, $O$. afrasiaticus is a main pest of date palm (Saleh and Hosny 1979; Elhalawany et al., 2017; Palevsky et al., 2004; Palevsky et al., 2003; Baankoud \& Basahih, 2000; Gassouma 2005; Al-Zadjali et al., 2006; Aldosari, S.A. 2009; Lakhdari et al., 2015). The mites feed on the green date fruit, covering bunches with dense webbing that hinders photosynthesis and accumulates much dust. 
Infested fruit become reddish, produce gum-like exudations, shrivel and may split, greatly reducing their market value. Heavy infestations can lead to partial or total yield loss. Chemical pesticides were used for mites control, in addition to the use of the host plant resistance, agricultural and biological control (Negm et al., 2015). Palevsky et al., (2004) evaluated six acaricides (i.e., hexythiazox, fenbutatin oxide, abamectin, fenazaquin, Etoxazole and bufenpyrade) on $O$. afrasiaticus.

The works of Arbabi et al. (2017) and Aldeghairi (2004) serve as ample guide to this literature. They evaluated the toxicity of certain insecticides and acaricides against $O$. afrasiaticus infested palm trees in different parts of the world. In the present study, the potential toxicity of five selected acarcides [abamectin (1.8\% EC), chlorfenapyr (36\% SC), fenopyroximate $(5 \%$ EC), cyflumetofen $(20 \%$ SC) and hexythiazox $(10 \%$ WP)] against the old world date mite, $O$. afrasiaticus in palm date $(P$. dactylifera Var. Siwi) in the New Valley was evaluated under field conditions.

\section{Materials and Methods}

The toxicity of five recommended acaricides against $O$. afrasiaticus adults was evaluated under field conditions in El-Kharga city
(The New Valley Governorate, Egypt).

Acaricides used: The formulations of abamectin $(1.8 \% \mathrm{EC})$, chlorfenapyr $(36 \%$ SC), fenopyroximate ( $5 \%$ EC), cyflumetofen ( $20 \%$ SC) and hexythiazox (10\% WP) were obtained from the Central Agricultural Pesticides Laboratory (CAPL) in Dokki, Giza, Egypt as gifts (Table 1).

The concentrations used in this study were: abamectin (1.8\%EC) at $50 \mathrm{ml} / 100 \mathrm{~L}$ water, chlorfenapyr $24 \%$ $\mathrm{SC}$ at $60 \mathrm{ml} / 100 \mathrm{~L}$ water, fenopyroximate $5 \% \mathrm{EC}$ at $50 \mathrm{ml} / 100 \mathrm{~L}$ water, cyflumetofen $(20 \% \mathrm{SC})$ at 40 $\mathrm{ml} / 100 \mathrm{~L}$ water and hexythiazox $10 \%$ $\mathrm{WP}$ at $20 \mathrm{~g} / 100 \mathrm{~L}$ water (Table 1).

The infected palm was randomly selected and the infected date bunches were divided into three replicates treated with acaricides. The numbers of mites were counted on 20 date fruits of each bunch using a binocular microscope. Records were taken after 1, 3, 7, 14, and 21 days. The pesticides were sprayed using 2 liters sprayer. The experiments were conducted during the period starting from July $15^{\text {th }}$ to August $6^{\text {th }}, 2017$.

The reduction percentages of mites were counted according to Henderson-Tilton's formula (Henderson and Tilton, 1955).

$$
\mathrm{n} \text { in Co before treatment } \times \mathrm{n} \text { in } \mathrm{T} \text { after treatment }
$$

Reduction $\%=1-($ $\mathbf{x} 100$

$\mathrm{n}$ in Co after treatment $\times \mathrm{n}$ in $\mathrm{T}$ before treatment

Where: $\mathrm{n}=$ number of mites, $\mathrm{T}=$ treated, $\mathrm{Co}=$ control 
Table 1. The acaricides used in the present study.

\begin{tabular}{|c|c|c|c|c|c|}
\hline \multirow{2}{*}{ No } & \multirow{2}{*}{$\begin{array}{c}\text { Common } \\
\text { name }\end{array}$} & \multirow{2}{*}{$\begin{array}{l}\text { Trade } \\
\text { name }\end{array}$} & \multirow{2}{*}{ Group } & \multicolumn{2}{|c|}{ Chemical } \\
\hline & & & & Name & structure \\
\hline 1 & Abamectin & $\begin{array}{l}\text { Agromec } \\
1.8 \% \mathrm{EC}\end{array}$ & Avermectin & \begin{tabular}{|l|} 
5-O- \\
demethylavermectin \\
B1a(i) mixture with \\
5-O-demethyl-25-de \\
(1-methylpropyl) - \\
25- (1 methylethyl) \\
avermactin B1a(ii)
\end{tabular} & \\
\hline 2 & Fenopyroximate & $\begin{array}{l}\text { Ortus } \\
\text { Super 5\% } \\
\text { EC }\end{array}$ & Pyrazolium & $\begin{array}{l}\text { 1,1-dimethylethyl } \\
\text { (E)-4- (((1.3- } \\
\text { dimethyl-5- } \\
\text { Phenoxy-1 H- } \\
\text { pyrazol- } \\
\text { 4-yl) methylen) } \\
\text { amino) methyl) } \\
\text { Benzoate }\end{array}$ & \\
\hline 3 & Hexythiazox & $\begin{array}{l}\text { Maccomite } \\
10 \% \mathrm{~W}\end{array}$ & Carboxamide & $\begin{array}{l}\text { (4RS,5RS)-5-(4- } \\
\text { Chlorphenyl)- } N- \\
\text { cyclohexyl-4- } \\
\text { methyl-2-oxo-1,3- } \\
\text { thiazolidin-3- } \\
\text { carboxamid }\end{array}$ & \\
\hline 4 & Chlorfenapyr & $\begin{array}{l}\text { Challenger } \\
\text { Super } 24 \% \\
\text { SC }\end{array}$ & Pyrroles & $\begin{array}{l}\text { 4-Brom-2-(4- } \\
\text { chlorphenyl)-1- } \\
\text { ethoxymethyl-5- } \\
\text { trifluormethyl- } \\
\text { pyrrol-3-carbonitril }\end{array}$ & \\
\hline 5 & Cyflumetofen & $\begin{array}{l}\text { Danisaraba } \\
(20 \% \mathrm{SC})\end{array}$ & Benzoylacetonitorile & $\begin{array}{l}\text { 2-Methoxyethyl } \\
\text { (RS)-2-(4-tert- } \\
\text { butylphenyl)-2- } \\
\text { cyano-3-oxo-3- } \\
(\alpha, \alpha, \alpha \text {-trifluoro-o- } \\
\text { tolyl)propionate }\end{array}$ & \\
\hline
\end{tabular}

\section{Results and Discussion}

Data in (Table 2 and Fig. 1) show the reduction percentages of five selected acaricides: abamectin, chlorfenapyr, fenopyroximate, cyflumetofen and hexythiazox against the $O$. afrasiaticus adults under field conditions.

The reduction percentages of abamectin, chlorfenapyr, fenopy- roximate, cyflumetofen and hexythiazox after one day treatment were $90.09,87.46,83.76,81.74$ and $62.61 \%$, respectively. While, after 3 days of treatment for the same acaricides were: 92.29, 89.32, 87.40, 84.50 and $65.84 \%$, respectively. Furthermore, after 7 days the reduction percentages were $95.23,92.20,89.32$, 86.54 and $68.80 \%$, respectively. The 
reduction percentages were 93.82, $91.72,88.40,84.83$ and $65.44 \%$, and $90.07,87.77,85.22, \quad 79.94$ and $62.89 \%$, after 14 and 21 days, respectively (Table 2). In general abamec- tin, chlorfenapyr, fenopyroximate, were more effective against the adult stage of the pest, followed by cyflumetofen and hexythiazox.

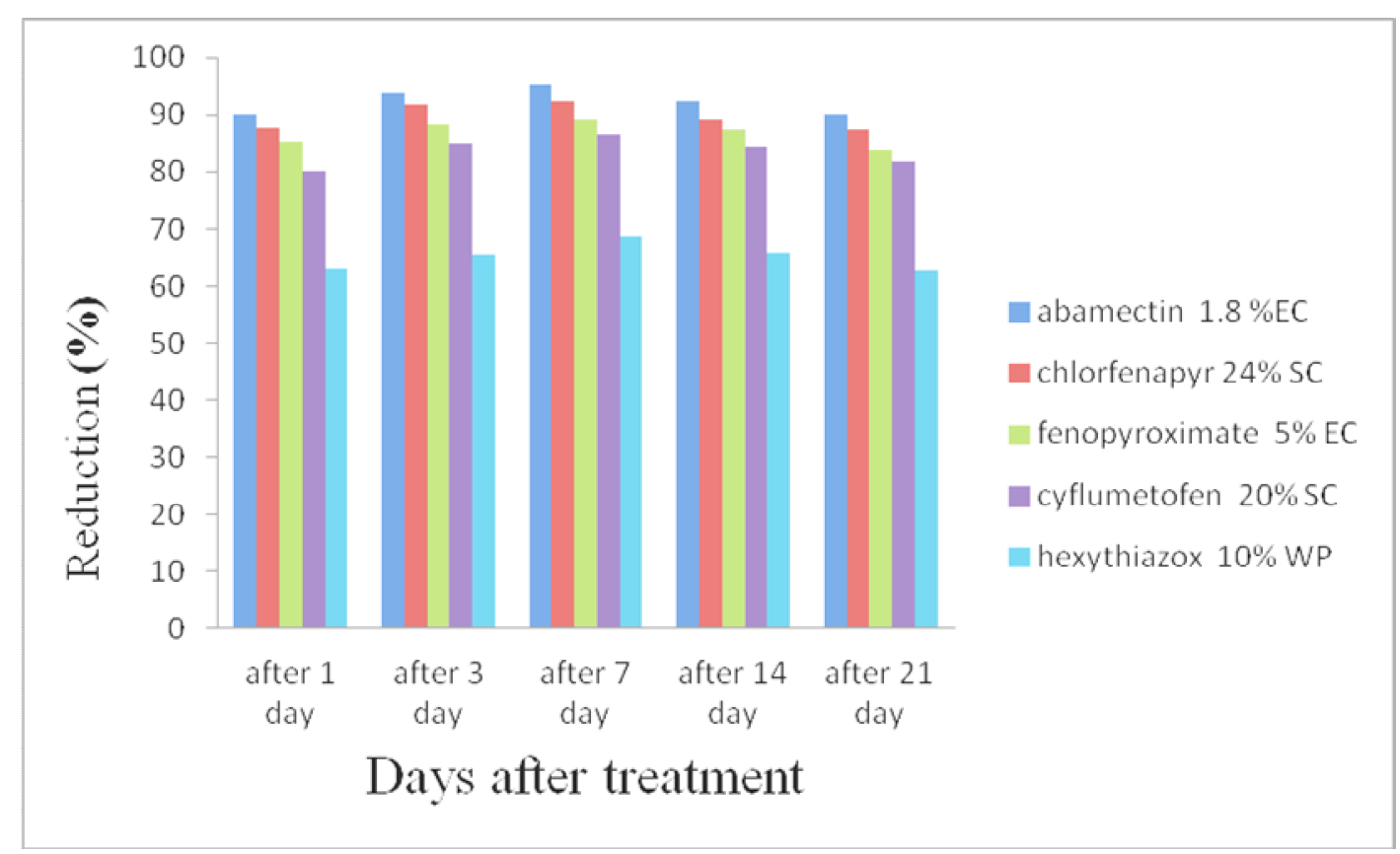

Fig. 1 The reduction percentages of five selected acaricides against the old world date mite, $O$. afrasiaticus on date palm fruits after 1, 3, 7, 14 and 21 days of treatment.

El-halawany, et al, (2017) stated that the challenger super and vertimec were very active against $O$. afrasiaticus, the reduction percentages were $91.93 \%$ and $91.60 \%$. Whereas, abroch, ortus super, tafaban and envidor gave reduction percentages ranged between $85.07 \%$ to $87.74 \%$. micronite, $\mathrm{KZ}$ oil and water only gave reduction percentages ranged between 71.77 and $82.82 \%$ after two weeks of application.

Table. 2 Effect of five selected acaricides against the old world date mite, $O$. afrasiaticus on date palm fruits after 1, 3, 7, 14 and 21 days of treatment.

\begin{tabular}{|c|c|c|c|c|c|c|}
\hline \multirow{3}{*}{ Acaricides } & \multicolumn{6}{|c|}{ Number of mite individuals/ 20 fruits } \\
\hline & \multirow{2}{*}{$\begin{array}{c}\text { Before } \\
\text { treatment }\end{array}$} & \multicolumn{5}{|c|}{ After treatment (days) } \\
\hline & & 1 & 3 & 7 & 14 & 21 \\
\hline Control & $2420 \mathrm{C} \pm 63.57$ & $2840 \mathrm{~A} \pm 57.24$ & $3000 \mathrm{~A} \pm 82.37$ & $3720 \mathrm{~A} \pm 114.5$ & $3930 \mathrm{~A} \pm 106.3$ & $4160 \mathrm{~A} \pm 89.03$ \\
\hline Abamectin & $3140 \mathrm{~A} \pm 47.26$ & $365 \mathrm{D} \pm 14.43$ & $300 \mathrm{D} \pm 5.77$ & $230 \mathrm{E} \pm 10.41$ & $315 \mathrm{D} \pm 8.66$ & $500 \mathrm{D} \pm 5.77$ \\
\hline Chlorfenapyr & $2380 \mathrm{C} \pm 96.44$ & $350 \mathrm{D} \pm 15.28$ & $315 \mathrm{D} \pm 10.41$ & $285 \mathrm{DE} \pm 13.23$ & $320 \mathrm{D} \pm 16.07$ & $500 \mathrm{D} \pm 15.28$ \\
\hline Fenopyroximate & $1890 \mathrm{D} \pm 66.58$ & $360 \mathrm{D} \pm 20.82$ & $295 \mathrm{D} \pm 12.58$ & $310 \mathrm{DE} \pm 15.28$ & $356 \mathrm{D} \pm 23.35$ & $480 \mathrm{D} \pm 11.55$ \\
\hline Cyflumetofen & $2030 \mathrm{D} \pm 65.06$ & $435 \mathrm{D} \pm 31.22$ & $390 \mathrm{CD} \pm 5.77$ & $420 \mathrm{CD} \pm 10.0$ & $500 \mathrm{CD} \pm 11.55$ & $700 \mathrm{C} \pm 5.77$ \\
\hline Hexythiazox & $1960 \mathrm{D} \pm 70.24$ & $860 \mathrm{~B} \pm 51.32$ & $830 \mathrm{~B} \pm 40.41$ & $940 \mathrm{~B} \pm 30.55$ & $1100 \mathrm{~B} \pm 125.8$ & $1250 \mathrm{~B} \pm 32.58$ \\
\hline Sig. F-test & $* *$ & $* *$ & $* *$ & $* *$ & $* *$ & $* *$ \\
\hline
\end{tabular}


More results were obtained on the toxicity of certain acaricides tested against mite species on date palm such as: Arbabi et al, (2017) assessed seven pesticides including amitraz, fenpropathrin, fenpyroximate, fenazaquin, propargite, tetradifon, and hexythiazox on $O$. afrasiaticus in Iran. The results indicated that, low doses of fenpyroximate, fenazaquin and hexythiazox caused high mortality rates. While, AlDoghairi (2004) evaluated the toxicity of eight acaricides against the same pest in Pakistan. The results showed that Kelthane and Neoron reduced mite infestations after the second week from application and continued until the termination of the experiment. On the other side, the ortus compound was also active on Panonychus ulmi on apple trees. While, Abd-Elhady and Heikal (2011) used three acaricides (i.e., flufenoxuron, fenpyroximate and abamectin) against $T$. urticae and its predator mite species, $P$. persimilis on apple orchards, a satisfactory results were recorded for $T$. urticae and in contrast with predator ( $P$. persimilis), in partially and/ or totally agreement with the present findings.

\section{References}

Abd-Elhady, H. K. and H. Heikal (2011). Selective toxicity of three acaricides to the two-spotted spider mite Tetranychus urticae and predatory mite Phytoseuilus persimilis in Apple Orchards. Journal of Entomology, 8 (6): 574-580.

Al-Doghairi, M.A. (2004). Effect of eight acaricides against the date dust mite, Oligonychus afrasiaticus (McGregor) (Acari: Tetranychidae). Pakistan Journal of Biological Sciences, 7, 11681171.

Aldosari, S.A. (2009). Occurrence of dust mite, Oligonychus afrasiaticus McG. on fruits, leaflets of some date palm trees and evaluation the efficiency of botanical compound, (biaco) as compared with some acaricides. Assiut University Bulletin of Environmental Research, 12, 69-77.

Al-Zadjali, T. S.; F. F. Abd-Allah and H. S. El-Haidari (2006). Insect pests attacking date palms and dates in Sultanate of Oman. Egyptian Journal of Agricultural Research, 84, 51-59.

Arbabi M; M. Latifian; M. Askari; M. T. Fassihi; M. R. Damghani; N. G. Z. Khiaban, and H. Rezai (2017). Evaluation of different treatments in control of Oligonychus afrasiaticus in date palm orchards of Iran. Persian Journal of Acarology, 6 (2): 125-135.

Baankoud, A. S. and G.S. Bass'haih (2000). A study on the effect of date palm dust mite Oligonychus afrasiaticus (McGregor) (Acarina: Tetranychidae) on the physiochemical characters of three different date varieties in Wadi Hadhramout, Yemen. Arab Journal of Plant Protection, 18, 82-85.

El-halawany, A. S.; A.S. Sanad and M. A. Rakha (2017). Field evaluation of date palm dust mite, Oligonychus afrasiaticus (McGregor) control on date palm trees in New Valley Governorate of Egypt. Journal of Biological Sciences, 9(3): 129134.

Gassouma, M. S. (2005). Pests of the date palm. Available at: http://ecoport.org/ep? Search Type $=$ slideshowViewandslidesho 
wId=133andcheckRequired $=Y$. Accessed on 15 Apr 2015.

Henderson, C. and E. Tilton (1955). Test with acaricides against the brown wheat mite. Journal of Economic Entomology, 84:157-161.

Lakhdari W.; A. Dehliz; F. Acheuk; A. Soud; H. Hammi; R. Mlik and B. Doumandji- Mitiche (2015). Acaricidal activity of aqueous extracts against the mite of date palm Oligonychus afrasiaticus Meg (Acari: Tetranychidae). Medicinal Plants Studies 2015; 3(6): 113117.

McGregor, E.A. (1939). The specific identity of the American date mite: description of two new species of Paratetranychus. Proceedings of the Entomological Society of Washington, 41, 247-256.

Negm, M. W.; G. J. De Moraes and T. M. Perring (2015). Mite pests of date palms. In: Wakil et al., (eds.), Sustainable pest management in date palm: Current status and emerging challenges, sustainability in plant and crop protection, pp 347- 390. Springer International Publishing Switzerland.

Palevsky, E.; O. Ucko; S. Peles; S. Yablonski and U. Gerson (2003). Species of Oligonychus infesting date palm cultivars in the Southern Arava Valley of Israel. Phytoparasitica, 31, 144-153.

Palevsky, E.; O. Ucko; S. Peles; S. Yablonski and U. Gerson (2004). Evaluation of control measures for Oligonychus afrasiaticus infesting date palm cultivars in the Southern Arava Valley of Israel. Crop Protection, 23, 387-392.

Saleh, M. R. A. and M. M. Hosny (1979). Observation on Oligonychus spp. occurring on date bunches (Acari: Tetranychidae). Ain Shams University Research Bulletin, 1114, 1-8. 
Oقييم خمسة مبيدات أكاروسية موصى بها ضد حلم الفبار، Oligonychus afrasiaticus (Acari: Tetranychidae) (McGregor)

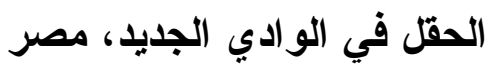

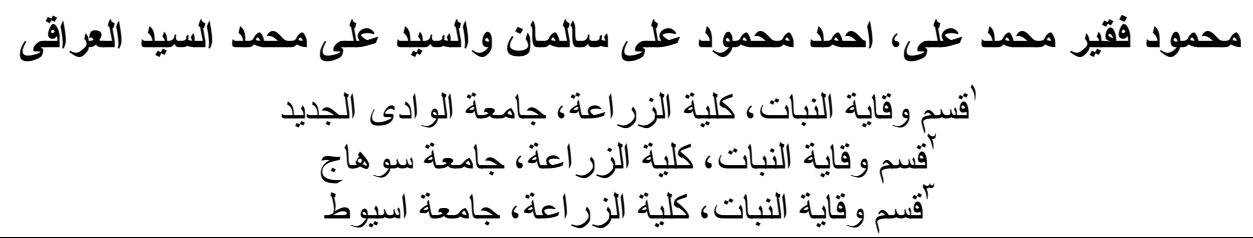

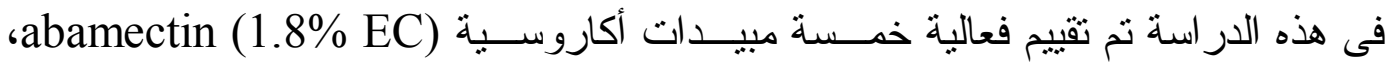
cyflumetofen ( $20 \%$ ،fenopyroximate (5\% EC) ،chlorfenapyr (36\% SC)

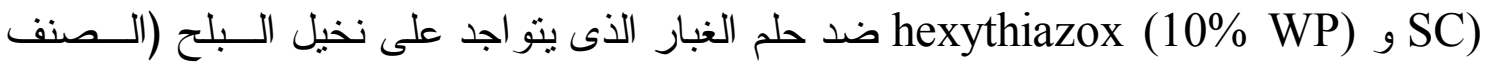

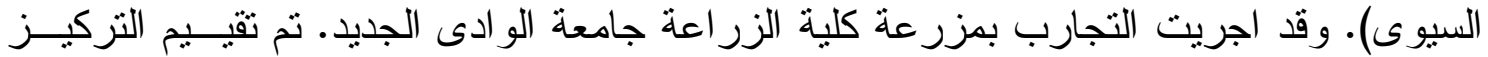

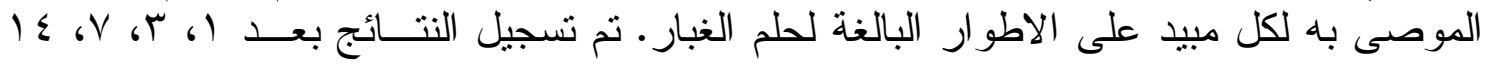

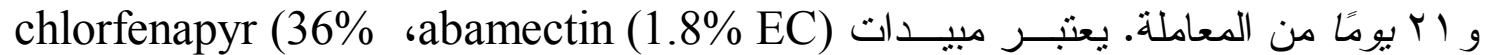

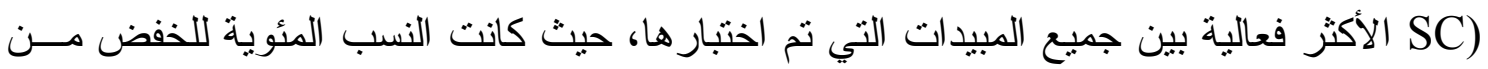

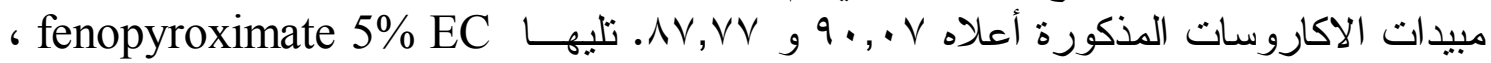

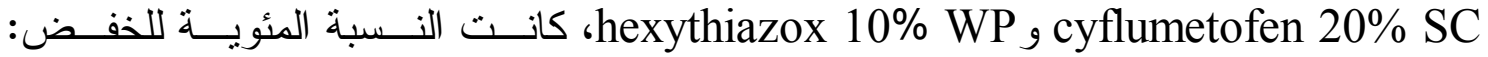

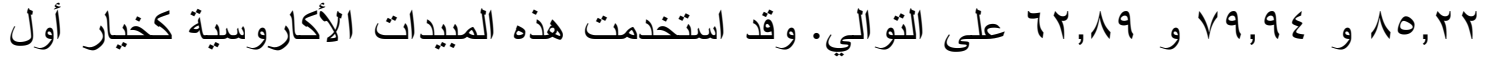
و اعتبرت اتجاهات مشجعة في السيطرة على حلم Ofrasiaticus في ملى محافظة الو ادي الجديد، 